\title{
Empirical Study on the Effectiveness of Network- based College English Teaching Mode
}

\author{
http://dx.doi.org/10.3991/ijet.v8i4.2912 \\ Jin Chengxing \\ Anhui Polytechnic University, Wuhu, China
}

\begin{abstract}
In order to study the effectiveness of the networkbased college English teaching mode, the paper firstly introduces the application background, its main features and theoretical basis. Then, an investigation via questionnaires was made to the two experiment classes and students' achievement test scores were compared between the two experiment classes and the control class. By analyzing the findings and comparing the achievement test scores, a conclusion was arrived that the students in the experiment classes benefits by developing an autonomy in English learning, getting highly motivated, becoming more independent of teachers and, more importantly, their comprehensive abilities were more enhanced, particularly in listening, speaking, reading and writing, while, on the other hand, teachers are still an important factor, acting its new role by designing the courseware, administrating students' autonomous learning, facilitating the learning process ,organizing the cooperative learning activities and giving instructions on using the network resources and learning strategies.
\end{abstract}

Index Terms-network-based English teaching mode, autonomous English learning, cooperative learning, multimedia technology

\section{INTRODUCTION}

21 st century is a cooperation and globalization century, so English, as an international language, is playing a more and more important role in cross-culture communications. Naturally, developing students' listening and speaking abilities are obviously the important goal of the college education. The application and diffusion of the modern information technology, especially the combination of multimedia techniques and web techniques, has provided powerful means to foreign language teaching. In order to satisfy the economic development and social needs, China has adopted the higher education development policy since late 1990s. Most universities and colleges have expanded in student numbers. Although each university or college starts to stress the introduction of new teachers, the proportion between teachers and students has still descended. According to statistics, only from 1998 to 2001 , the scope of enrollment expanded by $120 \%$. Nevertheless, the college teachers had increased by $31 \%$ [1]. Accordingly, the average class size has mushroomed greatly from 30 to 50 students in the previous time to above 60 or even 100 students due to the enrollment expansion. To solve the teaching staffs shortage, the Ministry of Education of China, urged and encouraged the universities or colleges to exercise the network-based college English teaching mode, firstly tried in 180 colleges and universities since 2004 and then spread throughout the country.

Anhui Polytechnic University (AHPU) has joined the network-based college English teaching trend ever since 2006. The paper attempts to elaborate the main features of the network-based college English teaching mode and to verify the hypothesis that the network-based English teaching mode can function better than the traditional English teaching mode through an investigation and data analysis.

\section{THE NETWORK-BASED COLLEGE ENGLISH TEACHING MODE}

In the traditional English teaching mode, teachers are the center, dominating the whole teaching process and learners are only the passive receptors, simply with textbooks, blackboards, chalks and tape recorders as the media. By contrast, the network-based English teaching mode is student-centered, stressing students' autonomy in constructing their own knowledge system(concepts, meanings, skills etc.) by involving themselves in the multimedia network environment and the teachers' role shifting from dominator to guide, instructor, facilitator, designer, organizer, cooperator etc. [2]. The new teaching mode satisfies the requirements for the development of students' individuality, respects their inner emotional experience, guides them to build up active learning attitude, stimulates their long-lasting enthusiasm, develops effective learning strategies and enhances the drive, competence and efficiency for autonomous learning [3]. Like anything else, the network-based English teaching mode has its advantages and its advantages.

\section{A. Advantages}

Alleviating teaching staffs shortage: In view of the marked increase in student enrollments and the relatively limited human resources, "colleges and universities need to remold the existing unitary teacher-centered mode of language teaching by introducing new teaching mode with the help of multimedia and network technology" [4]. The existing course wares exhibit a powerful function in correcting the assignments (writing, listening and even speaking). This saves teachers' labor to some extent so that they can do more research or improve their professional proficiency.

Realizing individualized and autonomous learning: The ultimate goal of the education is to develop independent learners. Dickinson holds that autonomous learning is both a learning attitude and an independent learning ability [5]. The new teaching mode is built on modern information and technology, particularly network 
technology, so that English learning will be free from the constraints of time or space and geared towards students' individualized and autonomous learning. When teachers give lessons to the students in the traditional way, it is impossible for them to pay much attention to every student. All students, whether their English levels are good or bad, accept the same content and the same rate of progress, which always leads to the difficulties: the higher-level students feel the content too easy and the lower level students feel it a little difficult to follow [6]. Fortunately, the network-based teaching mode solves the problem. Students can choose learning contents, rate of progress and tasks appropriate to their needs. Teachers can set different goals, questions and tasks for different students after fully considering their individual differences. The net-based learning has no space and time limitations, so the students can conduct their autonomous learning, with their individuality respected.

Promoting the formation of the cooperative learning mode: Cooperative learning, as a teaching concept, can remarkably improve the learning effect [7]. Long and Porter believed that the cooperative learning in language teaching has the following advantages: learners obtain more opportunities in language practice; learners' target language operating quality gets improved; learners' individualities are taken into account to some extent; learners' anxiety in using a foreign language are reduced and learners' enthusiasms are enhanced [8]. Through the cooperation process, members change their relationships from competition to cooperation. They need not only to realize their personal goals but also to help other members in the same group realize their goals. Only after the cooperation can the group reaches their anticipated goals. Besides, positive emotional factors play a significant role in language teaching and learning. A fine interpersonal relationship built in the process of cooperative learning will help to increase the members' confidence and selfrespect. The learner will have greater learning interests and gain better learning effects. Students in the networkbased English teaching mode especially need to have cooperative learning so as to fulfill the tasks or activities assigned by the teachers.

Enriched learning resources: One of the advantages for the net-based learning is its abundant resources [9]. It combines the advantages of videotape (authentic setting, multiple native speakers and contextually supported languages) with the advantages of computer-based instruction (opportunity to work alone, individual feedback, carefully mentioned progression of difficulty). Compared with the traditional teaching, the new mode can provide more national or even international learning resources. Students obtain valuable chances to indulge themselves in the sea of knowledge and information.

Arousing interests: The multimedia technology means the technology which utilizes computer to realize the comprehensive process of different types of information such as text, graphics, images, sounds, animations, videos etc, in order to establish logical relationship and humancomputer interaction [10]. The net-based English teaching makes use of the internet resources and provides vivid pictures and real voices. It achieves the successful combination of charts, articles, sounds and images, fully unfolding the process that the knowledge forms, which helps the students maintain the exuberant interests in learning and thus guarantees the classroom instruction optimization [11]. Interest is the students' most important teacher and is difficult to gain from the dull and boring contents on the blackboard in the traditional classroom. The learning environment in the new generation can benefit from augmentation with advanced information technologies [12].

Improving the output through the input: Krasen holds that only when the language input reaches a certain amount can the language output be ensured [13]. The objective of college English is to develop students' comprehensive abilities to use English, especially in listening and speaking. However, traditional English teaching focuses its attention on learning grammar, structure and some low-level techniques. The modern multimedia technology proves an easy access to an immense amount of authentic materials for oral/aural practice. Also, the well-designed software with an assessment system offer more opportunities to practice reading and writing and students get feedbacks immediately after submission. Thus, students' output abilities are enhanced through immense input.

\section{B. Disadvantages}

Courseware limitation: The teaching itself is flexible and changeable and the students' real level decides the teacher's teaching process. Although the present courseware is an extremely good one for the time being, the contents, even the processes, are fixed, lacking in changes. Teaching goes ahead in accordance with the designed contents in the courseware. This will weaken teacher's idiosyncrasy.

Lack in humanization: In the traditional classroom, students always see teacher's facial expressions and immediate feedbacks. While in the web-based teaching class, they are always facing the cool and emotionless computer screen. The sharp contrast will naturally lead the students to feel awkward more or less.

Students' lack in self-discipline: The abundant resources both have its advantages and disadvantages in English learning. On one hand, it can provide much useful information. On the other hand, too much information will distract the students' attention away and draw much of their attention to the colorful but less important resources. This would certainly weaken the students' focus of attention. Furthermore, it may lead to an unexpected result: some students even absorb less useful knowledge than those in the traditional teaching mode.

\section{THEORETICAL BASIS}

The network-based college English teaching mode is based on the constructivism theory launched by cognitive psychologist Piaget, which has been gradually developed and become one of the main trends in the teaching reforms since the 1990s [14]. The theory believes that the teaching should be student-centered and teacher should endeavor to create a learning atmosphere with teacher as a guide and students as the center by creating a content-based situation, provide the connections between the old and the new knowledge and help students construct the meanings of their knowledge obtained. The teaching process should be students' active exploration, active discovery of knowledge and the reconstruction of the meanings of their knowledge obtained. So the corresponding ideal learning environment should include the four elements: situation, 
cooperation, conversation and meaning construction [15]. The hypermedia technology in the network-based college English teaching facilitates the autonomous learning and the virtual technology provides an easy access to learners' situational learning and the communication technology helps in practicing the cooperative learning. Obviously, the network-based college English teaching mode provides an environment conforming to the constructivism theory and taking students as the center [16].

\section{INVESTIGATION AND DATA ANALYSIS}

\section{A. Purpose}

Assessment is a key component in college English teaching, which has the functions of direction, encouragement and promotion [17]. The assessment of the network-based English teaching can be achieved by a well-designed investigation and data analysis. The purpose is to testify the hypothesis that the network-based English teaching mode can function better than the traditional English teaching mode in the new era.

\section{B. Experiment}

Subject: Two network-based experiment classes of 164 freshmen, who entered AHPU in the fall of 2011 and were willing to join in the net-based teaching practice, are chosen as the experiment group. The other 81 freshmen from the traditional teaching class constitute the control group.

Table 1 shows that the two groups are much similar to each other in many aspects including class size, the family origin (from urban or the rural areas) and average entrance scores (against a total of 150). Statistical software (SPSS17.0) was employed to process the average college entrance scores. In Table 2, $\mathrm{F}=0.796<1$ and Sig=0.442 $>0.05$, which reveals that there is no significant difference between the two groups. Under this situation, any significant difference after a year' $s$ practice is supposed to be brought about by the adoption of the new teaching mode. contents. When they had face to face instructions in the classroom, the teacher's main focus was to give some instructions on the key points and check what they had mastered. The students completed their assignments, submitted them on the network and made use of their autonomous leaning time to finish the rest contents not carefully covered in the face to face instructions by the teacher. For the watching/listening/speaking class, the teacher set learning task for each student and provided online feedbacks, which was completed in the network language laboratory. Students' autonomous leaning was conducted on any computer connected to the campus network, while the teacher gave instructions, corrected their homework and answered their questions through BBS or Email and monitored their learning process, learning records and effects. Thanks to the test library equipped with the network resources, the teacher could easily devise or conduct examinations on the students, which realized the combination of formative assessment and the summative assessment. By contrast, the students in the traditional class had their reading /writing class and listening/speaking class respectively in the general classroom and the common language laboratory, with the teacher dominating the whole process. They handed in their homework in the form of paper and received feedbacks on their assignments at intervals between two teaching periods.

\section{Questionnaire and findings}

Questionnaire design: In order to research on the effects of the net-based English teaching in AHPU, a questionnaire is designed and investigations are conducted both at the beginning and the end of the first academic year to the students of the two net-based classes. The questionnaire consists of 9 questions: Questions 1-3 check students' main purpose of the network surfing, selflearning time after class and average on-line time per week, mainly to investigate students learning autonomy. Questions 4 to 6 aim to investigate students' opinions about their confidence in the net-based English learning, their interest and the multimedia's help in

Table 1. The basic info. between the experiment classes and the control class

\begin{tabular}{|c|c|c|c|c|}
\hline Class & No. & $\begin{array}{c}\text { Male/female ( } \\
\%)\end{array}$ & Rural/urban (\%) & $\begin{array}{c}\text { Average entrance } \\
\text { score }\end{array}$ \\
\hline $\begin{array}{c}\text { Experiment } \\
\text { class 1 }\end{array}$ & 82 & $58.8 / 41.2$ & $72.9 / 27.1$ & 120.80 \\
\hline $\begin{array}{c}\text { Experiment } \\
\text { class 2 }\end{array}$ & 82 & $60.0 / 40.0$ & $71.1 / 28.9$ & 121.77 \\
\hline Control class & 81 & $52.9 / 47.1$ & $71.4 / 28.6$ & \\
\hline
\end{tabular}

Table 2. One-way analysis of variance (ANOVA ) on the average scores

\begin{tabular}{|c|c|c|c|c|}
\hline & Sum of Squares & Mean Square & F & Sig. \\
\hline $\begin{array}{c}\text { Between } \\
\text { Groups }\end{array}$ & 31.058 & 15.529 & \multirow{2}{*}{0.796} & \multirow{2}{*}{0.442} \\
\hline Within Groups & 4724.122 & 19.521 & &
\end{tabular}

Experiment Implementation: The whole teaching experiment lasted for one year, with the experiment classes employing the network-based teaching mode. It required the students to preview the contents on the campus network by preparing the new words, phrases, structures and other important points related to the listening and speaking, in order to know their internal motivation. Questions 7 to 9 check students' opinions on the effectiveness of the network-based learning and teachers' role in helping improve English learning and in what aspects they need help most, so as to know their belief in the network-based learning, their reliance on the teachers, teachers' function in learning and their needs for instructions. 
PAPER

EMPIRICAL STUdy ON THE EFFeCTIVENESS OF NETWORK-BASEd COLLEGE ENGLISH TEACHING Mode

\section{Statistics:}

Table 3.

\begin{tabular}{|c|c|c|c|c|c|c|c|c|c|}
\hline \multirow{2}{*}{ Item } & \multicolumn{3}{|c|}{ 1. Purpose (\%) } & \multicolumn{3}{c|}{$\begin{array}{c}\text { 2. Average time on line } \\
\text { per week (\%) }\end{array}$} & \multicolumn{3}{c|}{$\begin{array}{c}\text { 3. Self-learning time } \\
\text { on English per day (\%) }\end{array}$} \\
\cline { 2 - 11 } & $\begin{array}{c}\text { searching } \\
\text { info. }\end{array}$ & chatting & others & zero & $\begin{array}{c}5-10 \\
\text { hrs }\end{array}$ & $\begin{array}{c}10 \mathrm{hrs} \\
\text { more }\end{array}$ & $>2 \mathrm{hrs}$ & $1-2 \mathrm{hrs}$ & $<1 \mathrm{hr}$ \\
\hline beginning & 37.6 & 34.4 & 28 & 13.8 & 83.3 & 2.9 & 9 & 63 & 28 \\
\hline end & 62.9 & 20.2 & 16.9 & 0 & 66 & 34 & 22.3 & 66 & 11.7 \\
\hline
\end{tabular}

Table 4.

\begin{tabular}{|c|c|c|c|c|c|c|c|c|c|}
\hline \multirow{3}{*}{ Item } & \multicolumn{6}{|c|}{ 4. Confidence (\%) } & \multicolumn{2}{c|}{$\begin{array}{c}\text { 5. Interest in net-based } \\
\text { English learning (\%) }\end{array}$} & \multicolumn{3}{c|}{$\begin{array}{c}\text { 6. multimedia helps in } \\
\text { speaking and listening(\%) }\end{array}$} \\
\cline { 2 - 11 } & great & medium & low & strong & average & low & great & medium & low \\
\hline \multirow{2}{*}{ beginning } & 26.9 & 58.7 & 14.4 & 64.1 & 30 & 5.9 & 25.7 & 44.6 & 29.7 \\
\hline end & 28.9 & 61.8 & 9.3 & 63.4 & 28 & 8.6 & 25.9 & 48.9 & 25.2 \\
\hline
\end{tabular}

Table 5

\begin{tabular}{|c|c|c|c|c|c|c|c|c|c|}
\hline \multirow{2}{*}{ Item } & \multicolumn{3}{|c|}{$\begin{array}{c}\text { 7. Effectiveness of } \\
\text { net-learning (\%) }\end{array}$} & \multicolumn{2}{c|}{ 8. Teachers' role (\%) } & \multicolumn{3}{c|}{$\begin{array}{c}\text { 9. Needing help } \\
\text { mostly in (\%) }\end{array}$} \\
\cline { 2 - 10 } & high & Med. & low & great & medium & others & $\begin{array}{c}\text { Oper. } \\
\text { skill }\end{array}$ & $\begin{array}{c}\text { Using } \\
\text { resources }\end{array}$ & $\begin{array}{c}\text { Learning } \\
\text { methods }\end{array}$ \\
\hline $\begin{array}{c}\text { beginnin } \\
\text { g }\end{array}$ & 16.2 & 62.3 & 21.5 & 18 & 53.7 & 28.3 & 23.7 & 30.5 & 45.8 \\
\hline the end & 36.1 & 62.4 & 2.5 & 15.9 & 46.2 & 37.9 & 9.6 & 32 & 58.4 \\
\hline
\end{tabular}

Findings: Table 3 indicates that most students spend longer time on the network, their main purpose shifts from chatting or others to searching information and their selflearning time on English after class increases, which means that they have developed an autonomous learning mode.

Table 4 reveals that most students are confident in the net-based English learning, retain a strong interest in it and that over $60 \%$ students agree that multimedia help in enhancing speaking and listening abilities, which means that they are highly motivated.

Table 5 suggests that most students agree that the netbased English learning is effective and that teachers are important to their learning, they have become more independent of teachers and what they need mostly is not the technical skills in computer operation but the instructions on how to take advantage of the resources and the methods to learn better.

\section{Achievement test scores comparisons}

The above findings clearly shows that after a year's experience, the students in the net-based experiment classes have developed an autonomous learning mode and that they are highly motivated and more independent in English learning, though they still need some instructions on using the resources and learning methods. Naturally, people may ask whether they have done better than those in the control class. So, when the first year ends, all the students are required to take the same examination including items like listening/speaking, reading, vocabulary/structure, cloze and writing. Average scores for the two experimental classes are 72.40 and 72.33 respectively, which are higher than the contrast group' $\mathrm{s}$ 69.78. Further statistical analysis was conducted by SPSS17.0 to show whether there exists significant differences between / among the three classes.

Table 6. One-way analysis of variance (ANOVA)

\begin{tabular}{|c|c|c|c|c|c|}
\hline & Sum of Squares & df & $\begin{array}{c}\text { Mean } \\
\text { Square }\end{array}$ & F & Sig. \\
\hline Between Groups & 342.442 & 2 & 177.221 & 4.751 & .012 \\
\hline Within Groups & 9026.224 & 242 & 37.299 & & \\
\hline Total & 9368.666 & 244 & & &
\end{tabular}


PAPER

EMPIRICAL STUdy ON THE EFFeCTIVENESS OF NETWORK-BASEd COLLEGE ENGLISH TEACHING Mode

Table 7. Multiple Comparison (Tamhane)

\begin{tabular}{|c|c|c|c|c|}
\hline & (I) group & Mean Difference (I-J) & Std. Error & Sig. \\
\hline $\begin{array}{c}\text { Experiment } \\
\text { class1 }\end{array}$ & $\begin{array}{c}\text { Experiment } \\
\text { class2 }\end{array}$ & .07118 & .87194 & 1.000 \\
\hline $\begin{array}{c}\text { Experiment } \\
\text { class2 }\end{array}$ & $\begin{array}{c}\text { Experiment } \\
\text { class1 }\end{array}$ & -.07118 & .87194 & 1.000 \\
\hline Contrast class & $2.6123\left(^{*}\right)$ & 1.06002 & .039 \\
\hline & $\begin{array}{c}\text { Experiment } \\
\text { class1 }\end{array}$ & $-2.62142\left(^{*}\right)$ & 1.04632 & .030 \\
\hline & $\begin{array}{c}\text { Experiment } \\
\text { class2 }\end{array}$ & $-2.61235\left(^{*}\right)$ & 1.06002 & .039 \\
\hline
\end{tabular}

*The mean difference is significant at the .05 level.

In Table 6, $\mathrm{F}=4.751>1$, sig. $=0.012<0.05$, it indicates that there are significant difference between the experiment group and the control group as a whole. Table 7 further reveals that there exists a significant difference between the experiment class 1 and the control class

$(\operatorname{sig}<0.05)$ and between the experiment class 2 and the control class $(\operatorname{sig}<0.05)$ and that there are no significant difference between the two experiment classes ( $\operatorname{sig}>0.05$ ). Considering that the average scores for each experiment class is higher than that of the control class, it is reasonable to infer that the experiment group has a better performance than the control group.

Comparison for each item is made by means of SPSS17.0 and shown in Table 8 and Table 9. can be inferred that the network- based English teaching mode has advantages in language input (listening and reading) and output (speaking and writing) but has no advantage in grammar learning, which is the strength of the traditional teaching mode.

\section{CONCLUSION}

The network-based English teaching mode is a completely new mode adopted in Chinese universities and colleges. It has exhibited its powerful functions in college English teaching, though it is still under debate over its advantages and disadvantages. Statistics through the investigation and data analysis on the new teaching mode practiced in AHPU indicates that the students who participated in the practice benefited a lot: they developed

Table 8. Independent sample T-test (experiment class 1-- control class)

\begin{tabular}{|l|c|c|c|c|c|c|}
\hline & \multicolumn{2}{|c|}{$\begin{array}{c}\text { Levene's Test for } \\
\text { Equality of } \\
\text { Variances }\end{array}$} & \multicolumn{5}{|c|}{ t-test for Equality of Means } \\
\cline { 2 - 7 } & $\mathrm{F}$ & Sig. & $\mathrm{t}$ & \multicolumn{1}{|c|}{ Sig. } & Mean Dif. & Std. Error Dif. \\
\hline Lis./speaking & 1.354 & .246 & 2.373 & .019 & .90924 & .38316 \\
\hline Reading & .223 & .638 & 2.114 & .036 & 1.11933 & .52948 \\
\hline Voca./str. & .439 & .509 & -.775 & .440 & -.24622 & .31777 \\
\hline Cloze & .159 & .691 & -.843 & .401 & -.14034 & .16656 \\
\hline Writing & .317 & .574 & 2.850 & .005 & .89118 & .31270 \\
\hline
\end{tabular}

Table 9. Independent sample T-test (experiment class 2 -- control class)

\begin{tabular}{|l|c|c|c|c|c|c|}
\hline & \multicolumn{2}{|c|}{$\begin{array}{c}\text { Levene's Test for } \\
\text { Equality of Variances }\end{array}$} & \multicolumn{4}{|c|}{ t-test for Equality of Means } \\
\cline { 2 - 7 } & $\mathrm{F}$ & \multicolumn{1}{c|}{ Sig. } & $\mathrm{t}$ & \multicolumn{1}{c|}{ Sig. } & Mean Dif. & Std. Error Dif. \\
\hline Lis./speaking & .101 & .751 & 2.255 & .025 & .77460 & .34348 \\
\hline Reading & .059 & .808 & 2.412 & .017 & 1.32063 & .54763 \\
\hline Voca./struc. & .007 & .932 & -.991 & .323 & -.28413 & .28667 \\
\hline Cloze & 2.866 & .092 & 1.162 & .247 & .17143 & .14755 \\
\hline Writing & .027 & .869 & 2.945 & .004 & .82778 & .28111 \\
\hline
\end{tabular}

Table 8 and Table 9 show that there exists a significant difference between each experiment class and the control class in listening/speaking, reading and writing and there is no significant difference in vocabulary/structure and Cloze. Considering that the average score in listening/speaking, reading and writing for each experiment class is higher than that of the control class, it an autonomy in English learning, got highly motivated, became more independent of teachers and most important of all, their comprehensive abilities were more enhanced than the students in the traditional teaching mode, particularly in listening, speaking, reading and writing. On the other hand, teachers are still an important factor, which should never be neglected. They should fully act its new role by designing the courseware, administrating students' autonomous learning, facilitating the learning 
PAPER

EMPIRICAL STUdy ON THE EFFECTIVENESS OF NETWORK-BASED COLLEGE ENGLISH TEACHING MODE

process, organizing the cooperative learning activities and giving instructions on using the network resources and learning methods.

\section{REFERENCES}

[1] Wang qiongman, Zhao bin, "Large Class College English Teaching: Problems and Countermeasures", Collection of Scientific Teaching, CST, no.9, pp 67-68, 2006

[2] Jin chengxing, Li xinguo, "Research on the Application of Multimedia-and-network-based College English Teaching Mode", Computer-Assisted Foreign language Education in China, CAFLE, vol.132, no.2, pp64-68, 2010

[3] Gao fan, Zhang yuanyuan, "The construction of the ecological model for college English network-based autonomous learning and classroom teaching". Journal of Hubei University of Economics(Humanities and Social Sciences), HBUE ,vol.7, no.6, pp.199-200, 2010

[4] Higher Education Section of the Ministry of Education, College English Curriculum Requirements, Shanghai Foreign Language Education Press, China, 2007

[5] Dickinson, L., Self-instruction in Language Learning, Cambridge University Press, Cambridge, 1987

[6] Yu fang, "Study on Multimedia-and-network-based College English Teaching Mode". Journal of East China Jiaotong University, ECJTU, vol.22, no.12, pp.270-272, 2005

[7] Shi jinfang, Ji rongqin, "Development of Web-based Autonomous Learning Ability of the Students in Universities of Science and Technology", Journal of Xi'an International Studies University, XISU, vol.18, no.2, pp.97-100, 2010

[8] Long, M. H. and P. A. Porter, "Group work, inter-language talk, and second language learning", TESOL Quarterly, TESOL, vol. 19,no.3, pp 207-228,1985 http://dx.doi.org/10.2307/3586827

[9] Shi lin, "A Study of the Ecological Web-based College English Teaching Environment from the Constructive Perspective", Computer-Assisted Foreign language Education in China, CAFLE, vol.145,no.3, pp 62-65, 2012

[10] Chen Qiaoping, "Research for Influence of Physical Education Multimedia Teaching on Sports Motivation of Students", AISS:
Advances in Information Sciences and Service Sciences, AICIT, vol.4, no.16, pp. 14-22, 2012 http://dx.doi.org/10.4156/aiss.vol4. issue 16.3

[11] Deng zhongyi, "The Advantages and the Drawbacks of Multimedia Teaching Way of the Computer", Journal of EEE, EEE, vol.28, no.1, pp. 98-103, 2006

[12] Jui-Hung Chen, Han-Bin Chang, "Immersive Learning Environment with Integrated Interactive Video and Ubiquiitous Technologies", JCIT: Journal of Convergence Information Technology, AICIT, vol.5, no.9, pp. 61-72, 2010 http://dx.doi.org/10.4156/jcit.vol5.issue9.6

[13] Krashen, Stephen D., The input hypothesis, Longman, London, 1985.

[14] Xie shengliang, "On College English Teaching in the Presence of Network", Computer-Assisted Foreign language Education in China, CAFLE, vol.121, no.3, pp42-45, 2008

[15] Li liqun, Shang jing, "On Improving the College English Teaching Quality", China University Teaching, CUT, vol.121, no.6, pp9092, 2007.

[16] Yu limin, Guo hongjie, "On the Application of the Internet in Foreign Language Learning: A Constructivist Learning Perspective", Foreign Languages in Fujian, FLFJ, vol.75, no.1, pp26-29, 2003

[17] Li Xinguo, "Computer-Web-Based Multimedia College English Teaching Assessment Model with Uncertain Linguistic Information", AISS: Advances in Information Sciences and Service Sciences, AICIT, vol.4, no.13, pp. 178-183, 2012 http://dx.doi.org/10.4156/aiss.vol4.issue13.23

\section{AUTHOR}

Jin Chengxing is with Anhui Polytechnic University, Wuhu 241000 China (e-mail: jincx2003@ahpu.edu.cn).

This work was supported in part by key project of Humanities and Social Sciences, Anhui Educational Commission under Grant 2011sk204zd and the teaching and research project of Anhui Polytechnic University under Grant 2010xjy35. Manuscript received 13 June 2013. Published as resubmitted by the author 8 August 2013. 